\title{
Organizing for Competitiveness - Structural and Process Characteristics of Organizational Design
}

\author{
Tomislav Hernaus' ${ }^{1}$ Ana Aleksic ${ }^{1}$, Maja Klindzic $^{1}$
}

\begin{abstract}
An emerging multidimensional approach to organizational design outlines the need for the alignment of relevant structural and process characteristics of organizations. However, neither the interaction of these characteristics nor their role and importance for organizational competitiveness is properly examined in the literature. Therefore, the main goal of this paper is to investigate the relationship between the structural and process characteristics of organizational design to determine how and to what extent these characteristics contribute to achieving a competitive advantage. The field survey was conducted on a cross-sectional sample of 134 Croatian companies. The research findings outlined the need for a new organizational design approach that emphasizes both the vertical and horizontal dimensions of design solutions. This paper contributes to previous research by showing that organizational design represents a source of competitive advantage only if structural and process characteristics are commonly designed. In addition, we confirmed that although structural characteristics are usually more often addressed, it is process characteristics that make a difference.
\end{abstract}

KEY WORDS: $\quad$ organizational design; structural characteristics; process characteristics; competitive advantage; Croatia

JEL Classification: L22; M1

${ }^{1}$ University of Zagreb, Croatia

\section{Introduction}

Organizational design has become an important and relevant topic both in theory and in practice. A turbulent and highly competitive business environment accompanied by a constant interplay of rising complexity and interdependence creates an ongoing demand for organizational designs that can respond to ㅁ new and more powerful coordination mechanisms

Correspondence concerning this article should be addressed to: Tomislav Hernaus, Department of Organization and Management Faculty of Economics and Business, University of Zagreb, Trg J. F. Kennedy 6, 10000 Zagreb, CROATIA. E-mail: thernaus@efzg.hr
(Galbraith, 2012). Additionally, contemporary organizations must be efficient, effective, flexible, agile, innovative, fast-cycled, responsive, and aligned. They must focus on increasing the capacity of existing resources as an additional strategy for meeting the resource demands of the business (Steinmetz, Bennet, \& Hakonsson, 2012). Although such organizational goals require very broad systemic efforts and call for numerous organizational interventions, differentiation and integration of activities can be recognized as one of the most relevant design issues (e.g., Dougherty, 2001; Lawrence \& Lorsch, 1967; Raisch et al., 2009). 
Differentiating and integrating units is a main task of organizational design that represents a primary driver of strategy execution. Organizational design per se should be understood as an organizational capability that could potentially become an important source of competitive advantage (e.g., Bryan \& Joyce, 2007; Galbraith, 2002; Lawler III \& Worley, 2006; Miller \& Whitney, 1999; Nadler \& Tushman, 1997; Powell, 1992; Walton \& Nadler, 1994). Organizational design capabilities are particularly relevant for medium and large organizations, determined by heavy information processing requirements, higher differentiation, and a large division of labor, and supplemented with diverse workforce and narrow job specialization. Those companies, more than the others, must be broken down into numerous small units so that employees care about their products or services and are capable of identifying with the organization's success (Lawler III, 1996).

Hierarchical decomposition (or structural differentiation) into units allows the efficient use of organizational resources and provides employees with an identifiable "home" within the larger organization. However, rather than solely focusing on understanding the vertical or structural characteristics of organizational design, managers and academicians alike should also address its horizontal or process characteristics and be able to design the relationship among various units within an organization.

Very few studies have simultaneously examined both the structural and process characteristics of organizational design. Historically, several authors have addressed the issue (e.g., Aiken, Bacharach, \& French, 1980; Bacharach \& Aiken, 1976; Hall, 1962; Mohr, 1971; Rousseau, 1978; Van de Ven \& Ferry, 1980), but recent empirical findings concerning the interaction of two sets of organizational characteristics and their possible outcomes are still rare (e.g., Turkulainen \& Ketokivi, 2013). Thus, the current study fills the research gap and sheds new light on the interplay among the structural and process characteristics of organizational design. By examining relationships between the two most important dimensions of organizing and designing, interesting insights may be recognized and integrated into organizational theory and practice. In particular, the differential importance of structural and process characteristics of an organization for the competitive role of its design solution will be recognized.

The paper consists of six main parts. Following the introduction, a review of the relevant literature addressing the structural and process characteristics of organizational design is provided. In the third section, the research goals and proposed hypotheses are presented, and in the fourth section, a methodological framework is thoroughly explained. The fifth section presents the results of the data analysis. The final section concludes with a summary of the main findings and offers research limitations and future research possibilities.

\section{Literature Review}

\section{Organizational structure and business processes}

Organizational structure and business processes are the main elements of organizational design (e.g., Shani \& Docherty, 2003). Both dimensions are important and necessary even though their focus is somewhat polarized. Whereas the vertical dimension of an organization decomposes hierarchical levels and provides stability and authority, the horizontal dimension emphasizes integration through better coordination, communication, and collaboration of various organizational units.

The structural and process characteristics of organizational design differ in many ways, but they are also strongly connected and complementary in nature. Henning (1934) and Nordsieck (1931) were among the first who addressed a need for the alignment of a static structure and dynamic processes within an organization (zur Muehlen, 2002). Prior research recognized various perspectives of the relationship between organizational structure and business processes. Historically, numerous authors primarily addressed the structural characteristics of organizational design (e.g., Blackburn, 1982; Child, 1973; Dalton et al., 1980; Fredrickson, 1986; Pugh et al., 1968). However, during the 1990s, business process reengineering (BPR) philosophy questioned and dismissed a structural component (e.g., Davenport, 1993; Davenport \& Short, 1990; Hammer, 1990; Hammer \& Champy, 1993). This dismissal was followed by a radical switch to the process view.

Nevertheless, Anthony, Dearden and Vancil (1972) have argued that the structural and process charac- 



\section{Process characteristics of organizational design} Although structural issues have dominated the research for almost half a century, process orientation has begun to gain momentum, largely on the wings of BPR and business process management (BPM). Organizations and work have increasingly been defined through their business processes - a natural part of thinking about how to make things work better (Hernaus, 2011a).

Whereas structural dimension explains how an organization is differentiated into specialized, self-contained units, process orientation is focused on the flow of work within organizations and offers a horizontal view of business activities. The process dimension of an organization integrates and coordinates previously differentiated units into the whole. It allows significant savings in terms of time, resources, and money while providing higher quality and better customer and employee satisfaction. As a result of process orientation, traditional functional barriers disappear and organizations become more integrated.

A small number of companies can still afford to function in a vacuum, produce low quality products or have slacks while doing business. An increasing number of organizations are turning to the process characteristics of their design solutions to improve coordination across multiple units or to reduce bottlenecks and non-value-added activities. These organizations are encouraged to align their structure more closely with their internal business processes, which can be understood as an interaction device and a binder among separated units and employees.

However, the process characteristics of organizational design have been less often empirically tested than their structural counterparts. These characteristics have mostly been observed through technology - a sequence of how the work is performed. Nevertheless, various process variables have been proposed and examined, particularly within the quality, supply chain, and operations management literature, such as interdependence, coordination, horizontal (workflow/ process/cross-functional) integration, process adaptability (flexibility), (statistical) process control, process management, and process technology. Within the context of the present study, it is particularly interesting to examine those process variables that are mainly focused on the relationship among organizational units, such as unit interdependence, process time efficiency, process interdependence, and unit focus. Inter-unit collaboration may in particular result in various types of synergistic advantages. While the chosen variables have not been commonly studied, they have often been emphasized as important (e.g., Andersen, 1999; Kiggundu, 1981; Spriggs, Jackson, \& Parker, 2000; Van de Ven \& Ferry, 1980; Victor \& Blackburn, 1987).

Unit interdependence shows a level of dependency or needed collaboration between different organizational units while trying to produce a product or offer a service (Parker \& Wall, 1998). It reflects itself through a workflow and exchange of necessary resources among units. Low unit interdependence implies that units can do their work independently of each other and have little need for interaction, consultation or the exchange of materials. On the other hand, high unit interdependence means that units must constantly exchange resources and cannot fulfill their goals without a common action (Daft, 2007).

Process throughput time, cycle time or process time efficiency represents a measure of process execution. It refers to the length of time that a job spent in these processes and includes the time associated with valueadding and non-value-adding activities. As one of the most important measures of process performance, this value is frequently the main focus when comparing the performance of alternative process designs (Laguna \& Marklund, 2005). Reduced cycle time is strongly related to achieving efficiency gains (Tenner \& DeToro, 1996) and as such is interesting for further study.

The process interdependence variable is related to Thompson's classification of technology. Namely, Thompson (1967) distinguished among three main types of technology: long-linked technology, mediating technology, and intensive technology. His types represent a continuum of possible interdependencies between various tasks, employees or units. The level of interdependence among tasks regarding a particular business process will strongly influence both technology and organizational structure (Jones, 2007).

Finally, Andersen (1999) argues that each unit seeks to maximize its influence and authority in the organization while simultaneously optimizing its performance level. A strong unit focus usually produces a situation in which the whole is far from being more than the sum of the individual elements, and in the 
worst case, far less. As a result, each organizational unit suboptimizes within its area of responsibility, which in turn leads to conflicting objectives and competitive actions among different departments.

\section{Research Goals and Hypotheses}

Several authors have already theoretically addressed the need for aligning the structural (vertical) and process (horizontal) characteristics of an organization (e.g., Anthony et al., 1972; Holtham, 1997; Kosiol, 1962; Telem, 1985). However, there is a lack of empirical studies that place the structural and process characteristics of organizational design within the same research context. Therefore, with the purpose of designing an organization that operates efficiently and effectively, organizational structure and business processes must be discussed and developed collaboratively and interactively. To gain a better understanding of those complex organizational issues, both structural and process aspects of organizational design were jointly observed in the present study. Their common ground and focus should contribute to a better understanding of current interactions and can potentially identify necessary areas of alignment. Thus, the main aim of the paper was to empirically investigate and demonstrate how and to what extent the interplay of two critical dimensions of organizational design contributes to achieving a competitive advantage. The aforementioned research goal led to the development of the hypotheses.

Traditionally, organizational design was understood as a narrow set of decisions related only to structural issues. Structural dimension and its characteristics, such as decentralization, standardization, differentiation, and formalization, were a focus of scientific research for decades. However, such an approach was one-dimensional and limited. Today, as global competitiveness and the IT revolution have dramatically changed the world of business, a new multidimensional perspective of organizational design has emerged (e.g., Galbraith, 2012; Strikwerda \& Stoelhorst, 2009). Accordingly, organizational design is defined much more broadly as a deliberate process of configuring structures, processes, reward systems, and people practices to create an effective organization capable of achieving the business strategy (Kates \& Galbraith, 2007). This means that structure is only one of the organizational design elements and can- not be solely designed to create capabilities that represent a source of competitive advantage.

$\mathrm{H}_{1}$ : Designing the structural characteristics of an organization does not lead to a competitive advantage.

Organizational design can only provide additional value and optimize firm resources if the structural characteristics of organizational design are commonly observed and concurrently aligned with its process characteristics. The desire to improve coordination across multiple, linked capabilities and to reduce nonvalue-added activities has recently encouraged organizations to align their structures more closely with their internal business processes (Hernaus, 2011b). As Groth (1999) has argued, to achieve the best possible results, managers should choose structures that match defined objectives, the nature of the required processes, and the systems central to those processes. Because the literature presents numerous disputes regarding the relationship and importance of organizational structure and business processes (e.g., Hernaus, 2008; Oden, 1999; Rummler \& Brache, 1995; Spanyi, 2003), it should be clarified whether their mutual design effort makes a difference in the global business arena.

$H_{2}$ : The synchronous design of an organization's structural and process characteristics produces a competitive advantage.

Numerous signs indicate the importance of lateral integration in contemporary organizations. The traditional organizational model, composed of functional units integrated at the corporate level, is being replaced by organizational models with the capability of integrating a larger number of organizational units with a common focus on customers, products, projects or processes (Galbraith, Lawler III et al., 1993). The new lateral orientation and lateral integrative mechanisms (e.g., Galbraith, 1994; Kates \& Galbraith, 2007; Mintzberg, 1979; Worren, 2012) have upgraded and, to a certain extent, been replaced by traditional hierarchical logic. However, this does not mean that existing structural characteristics are no more valid. On the contrary, the newly addressed process characteristics should be equally important and emphasized as their structural counterparts. 
$\mathrm{H}_{3}$ : The design of an organization's structural and process characteristics is equally important for gaining a competitive advantage.

\section{Research methodology}

To test the proposed hypotheses, the research methodology and instrument have been developed. A Likert-type survey questionnaire (1 - strongly disagree; 5 - strongly agree) supplemented with several open questions was created after a comprehensive desk research. The questionnaire was composed of 17 questions that examined eight organizational characteristics. All variables and questions have been tested for their validity and reliability. The measurement instrument is described in Table 1.

The data collection process began in November 2008 and lasted until February 2009. The self-administered questionnaires were distributed by postal mail to 1,200 randomly sampled small, medium and large companies listed by the Croatian Chamber of Economy. Questionnaires supplemented with a cover letter were sent to the CEOs of targeted organizations because they perennially dealt with organizational design issues and usually had positive insights into organizational characteristics (e.g., Gilley \& Maycunich, 2000).

After a few months of data collection, we received 144 answered questionnaires, producing a response rate of $12.00 \%$. The questionnaires were largely completed by key people in the organization, such as the CEO or his or her close associates, who were either subject-matter experts (chief HR officers and OD professionals) or well informed top and middle managers. The fact that the questionnaires were completed by highly positioned incumbents shows their interest in the research problem as well as the relevance of the issues studied. The final (total) sample consisted of 134 companies due to some missing data values and our decision to apply a list-wise deletion strategy.

The collected data have been further subsampled along the values of the dependent variable (ORGDESIGN - perceived role of organizational design in gaining competitive advantage) to obtain better insights and determine potential differences between the best and mediocre practices for designing organizations. This procedure was based on similar experiences from the field (e.g., Aiken et al., 1980;
Bacharach \& Aiken, 1976; Miller, 1988; Reimann, 1974; Zhang, Dolan, Lingham, \& Altman, 2009). Those companies whose respondents perceived that their organizational design represents a significant source of competitive advantage were grouped into the "upper sample" (values 4 to 5, N=54), while companies whose design solutions cannot be evaluated as contributive were represented in the "lower sample" (values 1 to $3, \mathrm{~N}=80$ ). The following figures show the independent characteristics of the total sample and two subsamples regarding their industry, size, and ownership structure (see Table 2).

The observed samples were cross-sectional in nature. They are mostly represented by privately owned, mid-sized companies in the manufacturing, construction, and sales industries. There were significantly more private companies and fewer public companies in the "upper" sample than in the "lower" sample. In addition, more than $35 \%$ of companies within the "upper" sample had more than 500 employees, while the same category contained less than $23 \%$ in the "lower" sample. Finally, more manufacturing companies were represented in the "upper" sample $(32.1 \%)$ than in the "lower" sample (only $21.5 \%$ ), but on the other hand, the former consisted of significantly fewer construction companies (less than $8.0 \%)$ than the latter (19.0\%). This means that respondents from different industries potentially understand the importance of organizational design differently.

\section{Data Analysis and Research Findings}

The data gathered were analyzed using the SPSS 18.0 software package. Histograms and normal probability plots showed a normal distribution, which was confirmed with acceptable values of Skewness and Kurtosis measures (within \pm 1.5 ). Furthermore, multicollinearity issues were not found within the data (VIFs below 1.5). Descriptive statistics for three observed samples (total, "upper" and "lower") clearly showed that the average values for each structural and process variable were higher in the case of the "upper" sample than in the "lower" sample. These were not true for two variables (UNITFOCUS and PROCESS1), but that result seemed reasonable because those variables were inversely defined. Detailed descriptive results per sample are shown in Table 3. 
Table 1. Measurement instrument description

\begin{tabular}{|c|c|c|c|c|}
\hline Code & Variable & Type & \# of items & Cronbach Alpha \\
\hline VERTDIF & $\begin{array}{l}\text { Vertical differentiation } \\
\text { - Number of hierarchical levels }\end{array}$ & structural & 1 & - \\
\hline AUTON & $\begin{array}{l}\text { Middle manager's autonomy } \\
\text { - Middle managers are autonomous in: } \\
\text { - Budget decisions } \\
\text { - Employee selection } \\
\text { - Employee compensations } \\
\text { - Purchase of equipment and materials } \\
\text { - Decisions about new programs } \\
\text { - Solving untypical situations }\end{array}$ & structural & 6 & .773 \\
\hline FORM & $\begin{array}{l}\text { Formalization } \\
\text { - Rules and procedures are in written form } \\
\text { - Managers follow written rules }\end{array}$ & structural & 2 & .744 \\
\hline JOBSPEC & $\begin{array}{l}\text { Job specialization } \\
\text { - Workplaces are specialized regarding } \\
\text { work activities and requirements for } \\
\text { specialized skills and expertise }\end{array}$ & structural & 1 & - \\
\hline UNITDEP & $\begin{array}{l}\text { Unit interdependence } \\
\text { - Organizational units need service, } \\
\text { resources or support of other units for } \\
\text { accomplishing their tasks and goals }\end{array}$ & process & 1 & - \\
\hline PROCESS1 & $\begin{array}{l}\text { Process time efficiency } \\
\text { - Organizational processes are slow }\end{array}$ & process & 1 & - \\
\hline PROCESS2 & $\begin{array}{l}\text { Process interdependence } \\
\text { - Processes are serial in nature, meaning } \\
\text { one process cannot start unless the other } \\
\text { has ended }\end{array}$ & process & 1 & - \\
\hline UNITFOCUS & $\begin{array}{l}\text { Unit focus } \\
\text { - Organizational units are oriented toward } \\
\text { protecting their area of activity rather } \\
\text { than servicing other units } \\
\text { - Organizational units place a higher } \\
\text { priority on satisfying unit goals than on } \\
\text { organizational goals } \\
\text { - Organizational units are mutually } \\
\text { competitive }\end{array}$ & process & 3 & .785 \\
\hline ORGDESIGN & $\begin{array}{l}\text { Organization design impact } \\
\text { - Organizational design contributes to } \\
\text { competitive advantage }\end{array}$ & outcome & 1 & - \\
\hline
\end{tabular}


Table 2. Total sample characteristics

\begin{tabular}{|c|c|c|c|}
\hline Independent characteristics & Total sample $(\mathrm{N}=134)$ & “Lower” sample $(\mathrm{N}=80)$ & “Upper” sample $(\mathrm{N}=54)$ \\
\hline \multicolumn{4}{|l|}{ Industry } \\
\hline Manufacturing & $25.8 \%$ & $21.5 \%$ & $32.1 \%$ \\
\hline Construction & $14.4 \%$ & $19.0 \%$ & $7.5 \%$ \\
\hline Wholesale and retail trade & $12.1 \%$ & $11.4 \%$ & $13.2 \%$ \\
\hline Tourism and catering & $6.1 \%$ & $7.6 \%$ & $3.8 \%$ \\
\hline Transport and communication & $6.8 \%$ & $8.9 \%$ & $3.8 \%$ \\
\hline Agriculture and forestry & $2.3 \%$ & $1.3 \%$ & $3.8 \%$ \\
\hline Finance, banking, and insurance & $2.3 \%$ & $3.8 \%$ & $3.8 \%$ \\
\hline Electricity, gas, and water supply & $9.1 \%$ & $12.7 \%$ & $3.8 \%$ \\
\hline Services & $5.3 \%$ & $5.1 \%$ & $5.7 \%$ \\
\hline Other & $15.9 \%$ & $8.9 \%$ & $26.4 \%$ \\
\hline \multicolumn{4}{|l|}{ Size (number of employees) } \\
\hline 50 or less & $11.2 \%$ & $10.0 \%$ & $13.0 \%$ \\
\hline $51-250$ & $42.5 \%$ & $46.3 \%$ & $37.0 \%$ \\
\hline $251-500$ & $18.7 \%$ & $21.3 \%$ & $14.8 \%$ \\
\hline $501-1000$ & $9.7 \%$ & $6.3 \%$ & $14.8 \%$ \\
\hline more than 1000 & $17.9 \%$ & $16.3 \%$ & $20.4 \%$ \\
\hline \multicolumn{4}{|l|}{ Ownership structure } \\
\hline Public & $11.9 \%$ & $13.8 \%$ & $9.3 \%$ \\
\hline Private domestic & $53.7 \%$ & $52.5 \%$ & $55.6 \%$ \\
\hline Private foreign & $14.2 \%$ & $10.0 \%$ & $20.4 \%$ \\
\hline Mixed & $14.9 \%$ & $15.0 \%$ & $14.8 \%$ \\
\hline Other & $5.2 \%$ & $8.8 \%$ & - \\
\hline
\end{tabular}


Table 3. Descriptive statistics for three samples

\begin{tabular}{|c|c|c|c|c|c|c|}
\hline \multirow{2}{*}{ Variable } & \multicolumn{2}{|c|}{ Total sample $(\mathrm{N}=134)$} & \multicolumn{2}{|c|}{ “Lower" sample $(\mathrm{N}=80)$} & \multicolumn{2}{|c|}{ "Upper" sample $(\mathrm{N}=54)$} \\
\hline & Mean & Std. Deviation & Mean & Std. Deviation & Mean & Std. Deviation \\
\hline VERTDIF & 2.639 & 1.093 & 2.653 & 1.140 & 2.656 & 1.082 \\
\hline AUTON & 3.341 & .646 & 3.228 & .663 & 3.501 & .616 \\
\hline FORM & 3.975 & .733 & 3.865 & .701 & 4.067 & .774 \\
\hline JOBSPEC & 3.832 & .605 & 3.738 & .545 & 3.924 & .663 \\
\hline UNITDEP & 3.839 & .657 & 3.800 & .719 & 3.879 & .544 \\
\hline PROCESS1 & 2.688 & 1.183 & 2.772 & 1.154 & 2.571 & 1.256 \\
\hline PROCESS2 & 3.094 & 1.203 & 3.063 & 1.060 & 3.251 & 1.353 \\
\hline UNITFOCUS & 2.288 & .924 & 2.425 & .906 & 2.120 & .919 \\
\hline ORGDESIGN & 3.172 & 1.015 & 2.525 & .779 & 4.157 & .365 \\
\hline
\end{tabular}

Comparing subsamples, t-test for Equality of Means has shown statistically significant differences at the level .90 in three variables (AUTON, JOBSPEC, and UNITFOCUS). This means that in companies with value-adding or "competitive" organizational design practices, there is a higher level of decentralization $(\mathrm{MD}=.266, \mathrm{df}=125, \mathrm{p}=.024)$, deeper job specialization $(\mathrm{MD}=.188, \mathrm{df}=132, \mathrm{p}=.076)$ and smaller interunit competition $(\mathrm{MD}=-.306, \mathrm{df}=131, \mathrm{p}=.060)$ than in companies where organizational design practices do not make a difference (see Table 4).

Furthermore, a correlation analysis was conducted separately for each subsample. The results have clearly shown that in the case of companies in which organizational design is perceived as a source of competitive advantage, there were more significant relationships reported between two types of independent variables (structural and process, respectively) than in the opposite subsample. Additionally, relationships that were present in both subsamples were significantly stronger in the "upper" sample, which means that in those com- panies, there was a stronger emphasis on the alignment of vertical and horizontal dimensions of organizations. The correlation matrix for two subsamples ("lower" sample results are shown in the bottom part, while the "upper" sample results in the upper part) analyzed is shown in Table 5.

Statistically significant relationships between structural and process variables were moderate and present in $22.22 \%$ of all possible relationships within the "lower" sampled companies, while in the "upper" sampled companies this percentage was much higher, counting $61.11 \%$. Stronger relationships between independent and outcome variables were present in the latter, which means that the proper mix of structural and process characteristics leads toward more significant and "competitive" organizational design practice. The existence of rules and procedures had the strongest positive influence on the outcome variable $(\rho=.362, p<.01$, $\mathrm{N}=54$ ), and the time efficiency process had the largest negative influence $(\rho=-.348, \mathrm{p}<.01, \mathrm{~N}=54)$. The highest Pearson correlation coefficients have been noticed 
Table 4. Independent samples t-test ("Upper" and "lower" sample comparison)

\begin{tabular}{|c|c|c|c|c|c|c|}
\hline \multirow{2}{*}{ Variables } & \multicolumn{2}{|c|}{$\begin{array}{c}\text { Levene's Test for Equality of } \\
\text { Variances }\end{array}$} & \multicolumn{4}{|c|}{ t-test for Equality of Means } \\
\hline & $F$ & Sig. & $\mathrm{t}$ & df & Sig. (2-tailed) & $\begin{array}{c}\text { Mean } \\
\text { difference }\end{array}$ \\
\hline VERTDIF & .214 & .645 & -.089 & 122 & .929 & -.018 \\
\hline AUTON & .004 & .950 & 2.286 & 125 & .024 & .266 \\
\hline FORM & 1.578 & .211 & 1.393 & 130 & .166 & .181 \\
\hline JOBSPEC & .034 & .855 & 1.789 & 132 & .076 & .188 \\
\hline UNITDEP & 4.188 & .043 & .609 & 132 & .544 & .070 \\
\hline PROCESS1 & 1.469 & .228 & -.796 & 130 & .428 & -.168 \\
\hline PROCESS2 & 9.375 & .003 & .777 & 131 & .439 & .164 \\
\hline UNITFOCUS & .035 & .851 & -1.900 & 131 & .060 & -.306 \\
\hline
\end{tabular}

Table 5. Correlation matrix ("Upper" and "lower" sample comparison)

\begin{tabular}{|c|c|c|c|c|c|c|c|c|c|}
\hline & VERTDIF & AUTON & FORM & JOBSPEC & UNITDEP & PROCESS1 & PROCESS2 & UNITFOCUS & ORGDESIGN \\
\hline VERTDIF & & .098 & .100 & $-.146^{*}$ & .029 & $.161^{*}$ & $.187^{* *}$ & $.222^{* *}$ & $.257^{* *}$ \\
\hline AUTON & .021 & & $.311^{* *}$ & .095 & .005 & $-.238^{* *}$ & .093 & .012 & $.151^{*}$ \\
\hline FORM & .018 & -.044 & & $.378^{* *}$ & -.120 & $-.209^{* *}$ & $.178^{* *}$ & $-.199^{* *}$ & $.362^{* *}$ \\
\hline JOBSPEC & .104 & -.095 & .012 & & -.126 & -.064 & $.161^{*}$ & $-.163^{*}$ & -.043 \\
\hline UNITDEP & .045 & -.074 & .059 & .024 & & $-.217^{* *}$ & -.014 & -.040 & $.210^{* *}$ \\
\hline PROCESSI & $.178^{*}$ & .006 & $-.307^{* *}$ & -.087 & .071 & & $.134^{*}$ & $.493^{* *}$ & $-.348^{* *}$ \\
\hline PROCESS2 & .131 & $-.161^{*}$ & -.093 & $-.179^{*}$ & -.042 & .086 & & $.192^{* *}$ & $.242^{* *}$ \\
\hline UNITFOCUS & .087 & $-.179^{*}$ & $-.283^{* *}$ & -.080 & -.110 & $.360^{* *}$ & .124 & & .011 \\
\hline ORGDESIGN & .119 & .064 & $.334^{* *}$ & .064 & .006 & -.137 & .043 & -.070 & \\
\hline
\end{tabular}

Notes:

* Correlation is significant at the 05 level (2-tailed).

** Correlation is significant at the .01 level (2-tailed). 

Table 6. Regression model fit comparison

\begin{tabular}{|c|c|c|c|c|c|c|}
\hline \multirow{2}{*}{ Variables } & \multicolumn{2}{|c|}{ Total sample } & \multicolumn{2}{|c|}{ "Lower" sample } & \multicolumn{2}{|c|}{ "Upper" sample } \\
\hline & Adj. $R^{2}$ & p-value & Adj. $R^{2}$ & p-value & Adj. $\mathrm{R}^{2}$ & $p$-value \\
\hline Structural & .116 & .001 & .156 & .006 & .106 & .057 \\
\hline Process & .067 & .065 & -.001 & .425 & .155 & .016 \\
\hline Structural and process & .110 & .005 & .123 & .045 & .240 & .010 \\
\hline
\end{tabular}

\section{Discussion and Conclusion}

This study contributed to filling the research gap in the literature. The data analysis revealed some interesting insights regarding the interplay between the structural and process characteristics of organizational design. The correlation analysis, in conjunction with the results of the multiple regression analyses, indicated that both vertical and horizontal dimensions are extremely important and should be designed together. Organizational design was not considered a source of competitive advantage in those companies that only addressed its structural aspects. Their traditional understanding of the organizational design concept has been a strong constraint to the development of this internal organizational capability. The same is obvious from a comparison of adjusted $\mathrm{R}^{2}$ coefficients between the "lower" and "upper" samples, where in the former process characteristics were nonsignificant predictors of variance in the dependent variable, while in the latter their influence was much stronger with $15.5 \%$ of the variance explained. In other words, it is obvious that organizational design is not perceived as an important issue and a potential source of competitive advantage in those companies that strongly emphasized only its structural aspects. Although the structural design of organizations was dominant throughout decades (e.g., Griffin, 1982; Kilmann, Pondy, \& Slevin, 1976; Porter, Lawler III, \& Hackman, 1975), it is clear that a new era of organizational design theory and practice has arrived (e.g., Galbraith, 2002; Howard et al., 1994; Nadler, Gerstein, Shaw et al., 1992; Stanford, 2005).
Regarding the organizing practices of companies from the "upper" sample, we found that those with more effective organizational design solutions had commonly designed structural and process characteristics, while companies from the "lower" sample that were solely focused on structural issues completely missed the positive market effects of their organizational design. The results of a correlation analysis confirmed that a larger number and more intensive relationships existed in the case of companies where organizational design was understood as a valueadding activity. Obviously, to be successful, companies must align various design elements, particularly organizational structure and business processes, which are among the most important ones (e.g., Galbraith, 2002; Kettinger \& Teng, 1998; Spanyi, 2003; Worren, 2012).

Although structural and process characteristics are both important for successful organizational design and effectiveness, contingency lenses should be applied because their importance could significantly vary across contexts. Nevertheless, this should not discourage managers to continually emphasize both vertical and horizontal dimensions of organizational design solutions. They should bear in mind that although structural characteristics are usually more often addressed, process characteristics are the characteristics that make a difference. By emphasizing process orientation, coordination and communication between people and units, lateral integrative mechanisms, and the flow of work within business processes, managers can make their organizational design the key ingredient for achieving business success. 
Nevertheless, we should be aware of certain research limitations. Rather small subsamples can lead to overgeneralization based on the very small amount of data. A much broader pool of organizations should be studied to gain better insights into patterns of organizational design. There are also potential problems of self-reports and common-method bias because the same respondents have answered on both independent and dependent variables. Objective measures and more respondents per company should be used in future studies to mitigate subjectivity and bias issues. Furthermore, our conclusions are based on low values of Adj. $\mathrm{R}^{2}$ coefficients, which indicate that the structural and process characteristics of organizational design are important, but they are not exhaustive. They should be supplemented with other relevant organizational characteristics recognized in the literature, such as strategic, knowledge, and social characteristics (e.g., Hernaus, 2010). Additionally, a choice of the measurement instrument could be somewhat problematic because there are often numerous distinct scales of the same phenomenon developed in the literature.

Despite potential limitations, the research findings have offered an insight into the core of organizational design - intertwined relationships between organizational structure and business processes. Future research activities should continue along the same path and investigate a broader set of organizational characteristics as well as relate those characteristics to organizational effectiveness outcomes. More rigorous conclusions will be possible if researchers focused on the lower levels of analysis. By conducting research at the unit (e.g., Eisenhardt \& Brown, 1999; Karim, 2006; 2009) or work level (e.g., Garg \& Rastogi, 2005; Gittell, et al., 2008; Grant, Fried, \& Juillerat, 2010; Humphrey et al., 2007), deeper insights into desirable and "competitive" organizational design practice will be achieved.

\section{References}

Aiken, M., Bacharach, S. B., \& French, J. L. (1980). Organizational structure, work process, and proposal making in administrative bureaucracies. Academy of Management Journal, 23 (4), 631-652. Andersen, B. (1999). Business Process Improvement Toolbox. Milwaukee, WI: ASQ Quality Press.

Anthony, R. N., Dearden, J., \& Vancil, R. F. (1965). Management Control Systems, Text, Cases and Readings. Homewood, IL: Irwin.
Bacharach, S. B., \& Aiken, M. (1976). Structural and Process Constraints on Influence in Organizations: A Level-Specific Analysis. Administrative Science Quarterly, 21 (4), 623-642.

Blackburn, R. S. (1982). Dimensions of Structure: A Review and Reappraisal. Academy of Management Review, 7 (1), 59-66.

Blau, P. M. (1970). A Formal Theory of Differentiation in Organizations. American Sociological Review, 35 (2), 201-218.

Bryan, L. L., \& Joyce, C. I. (2007). Better Strategy through Organizational Design. McKinsey Quarterly, 2, 21-29.

Burlton, R. T. (2001). Business Process Management: Profiting from Process. Indianapolis, IN: Sams.

Burton, R. M., \& Obel, B. (2004). Strategic Organizational Diagnosis and Design: The Dynamics of Fit ( $3^{\text {rd }}$ ed.). Berlin: Springer.

Burton, R. M., DeSanctis, G., \& Obel, B. (2006). Organizational Design: A Step-by-Step Approach. Cambridge, UK: Cambridge University Press.

Child, J. (1974). Managerial and Organizational Factors Associated with Company Performance. Journal of Management Studies, 11 (3), 175-189.

Claver-Cortés, E., Pertusa-Ortega, E. M., \& MolinaAzorín, J. F. (2012). Characteristics of organizational structure relating to hybrid competitive strategy: Implications for performance. Journal of Business Research, 65 (7), 993-1002.

Daft, R. L. (2007). Understanding the Theory and Design of Organizations (International student edition). Mason, $\mathrm{OH}$ : Thomson South-Western.

Dalton, D. R., Todor, W. D., Spendolini, M. J., Fielding, G. J., \& Porter, L. W. (1980). Organization structure and performance: a critical review. Academy of Management Review, 5(1), 49-64.

Davenport, T. H. (1993). Process Innovation: Reengineering Work through Information Technology. Boston, MA: Harvard Business School Press.

Davenport, T. H., \& Short, J. (1990). The New Industrial Engineering: Information Technology and Business Process Redesign. Sloan Management Review, 31 (4), 11-27.

Dougherty, D. (2001). Reimagining the Differentiation and Integration of Work for Sustained Product Innovation. Organization Science, 12 (5), 612-631. 
Dumas, M., La Rosa, M., Mendling, J., \& Reijers, H. A. (2013). Fundamentals of Business Process Management. Berlin: Springer.

Eisenhardt, K. M., \& Brown, S. L. (1999). Patching: Restitching Business Portfolios in Dynamic Markets. Harvard Business Review, 77 (3), 72-82.

Fredrickson, J. W. (1986). The strategic decision process and the organizational structure. Academy of Management Review, 11 (2), 280-297.

Galbraith, J. R. (1994). Competing With Flexible Lateral Organizations ( $2^{\text {nd }}$ ed.). Reading, MA: AddisonWesley.

Galbraith, J. R. (2002). Designing Organizations: An Executive Guide to Strategy, Structure, and Process. San Francisco, CA: Jossey-Bass.

Galbraith, J. R. (2012). The Future of Organization Design. Journal of Organization Design, 1(1), 3-6.

Galbraith, J. R., Lawler III, E. E. et al. (1993). Organizing for the Future. San Francisco, CA: Jossey-Bass.

Garg, P., \& Rastogi, R. (2005). New model of job design: motivating employees' performance. The Journal of Management Development, 25 (6), 572587.

Gilley, J. W., \& Maycunich, A. (2000). Organizational learning performance and change - an introduction to strategic human resource development. Cambridge, MA: Perseus Publishing.

Gittell, J. H., Weinberg, D., Bennett, A., \& Miller, J. A. (2008). Is the Doctor In? A Relational Approach to Job Design and the Coordination of Work. Human Resource Management, 47 (4), 729-755.

Govindarajan, V. (1988). A Contingency Approach to Strategy Implementation at the Business-Unit Level: Integrating Administrative Mechanisms with Strategy. Academy of Management Journal, 31 (4), 828-853.

Grant, A. M., Fried, Y., \& Juillerat, T. (2010). Work Matters: Job Design in Classic and Contemporary Perspectives. In S. Zedeck (Ed.), APA Handbook of Industrial and Organizational Psychology, (Vol. 1) (pp. 417-453). Washington, DC: American Psychological Association.

Griffin, R. W. (1982). Task Design: An Integrative Approach. Glenview, IL: Scott, Foresman and Co.

Groth, L. (1999). Future Organizational Design - The Scope for the IT-based Enterprise. Chichester, UK: John Wiley \& Sons.
Hage, J., \& Aiken, M. (1967). Program Change and Organizational Properties: A Comparative Analysis. American Journal of Sociology, 72 (5), 503-519.

Hall, R. H. (1962). Intraorganizational Structural Variation: Application of the Bureucratic Model. Administrative Science Quarterly, 7 (3), 295-308.

Hammer, M. (1990). Re-engineering Work: Don't Automate, Obliterate. Harvard Business Review, 90 (4), 104-112.

Hammer, M., \& Champy, J. (1993). Reengineering the Corporation: A Manifesto for Business Revolution. New York, NY: HarperCollins Publishers.

Harmon, P. (2007). Business Process Change: A Guide for Business Managers and BPM and Six Sigma Professionals. Burlington, MA: Morgan Kaufmann.

Henning, K. W. (1934). Einfuhrung in die betriebswirtschaftliche Organisationslehre [Introduction to Organizational Theory]. Berlin: Springer.

Hernaus, T. (2008, May). Process-based Organization Design Model: Theoretical Review and Model Conceptualization. Paper presented at Third International Workshop on Organization Design, Aarhus School of Business, Aarhus.

Hernaus, T. (2010). Integrating macro- and micro-organizational variables through multilevel approach. (Unpublished doctoral thesis). Zagreb: University of Zagreb.

Hernaus, T. (2011a). The Process-Based Face of Organizations. In M. A. Sarlak (Ed.), The New Faces of Organizations in the 21st Century, (Vol. 2) (pp. 3380). Toronto: NAISIT Publishers.

Hernaus, T. (2011b). Business Trends and Tendencies in Organization Design and Work Design Practice: Identifying Cause-and-Effect Relationships. Business Systems Research, 2 (1), 4-16.

Holtham, C. (1997). Business Process Re-engineering: Contrasting What It is with What It is Not. In C. Coulson-Thomas (Ed.), Business Process Re-engineering: Myth or Reality (pp. 61-80). London, UK: Kogan Page.

Howard, A. et al. (1994). Diagnosis for Organizational Change: Methods and Models. New York, NY: The Gilford Press.

Humphrey, S. E., Nahrgang, J. D., \& Morgeson, F. P. (2007). Integrating Motivational, Social, and Contextual 
Work Design Features: A Meta-Analytic Summary and Theoretical Extension of the Work Design Literature. Journal of Applied Psychology, 92 (5), 1332-1356.

Jones, G. R. (2007). Organizational Theory, Design, and Change ( $5^{\text {th }}$ ed.). New Jersey, NJ: Prentice Hall.

Karim, S. (2006). Modularity in Organizational Structure: The Reconfiguration of Internally Developed and Acquired Business Units. Strategic Management Journal, 27 (9), 799-823.

Karim, S. (2009). Business unit reorganization and innovation in new product markets. Management Science, 55 (7), 1237-1254.

Kates, A., \& Galbraith, J. R. (2007). Designing Your Organization: Using the Star Model to Solve 5 Critical Design Challenges. San Francisco, CA: Jossey-Bass.

Kettinger, W. J., \& Teng, J. T. C. (1998). Aligning BPR to Strategy: A Framework for Analysis. Long Range Planning, 31 (1), 93-107.

Kiggundu, M. N. (1981). Task Interdependence and the Theory of Job Design. Academy of Management Review, 6 (3), 499-508.

Kilmann, R. H., Pondy, L. R., \& Slevin, D. P. (1976). Directions of Research on Organization Design. In R. H. Kilmann, L. R. Pondy, \& D. P. Slevin (Eds.), The Management of Organization Design, (Vol. 2) (pp. 9-19). Amsterdam: North-Holland.

Kosiol, E. (1962). Organization der Unternehmung [Organization of Enterprise]. Wiesbaden: Gabler Verlag.

Laguna, M., \& Marklund, J. (2005). Business Process Modeling, Simulation, and Design. New Jersey, NJ: Prentice Hall.

Lawler III, E. E. (1996). From the Ground Up - Six Principles for Building the New Logic Corporation. San Francisco, CA: Jossey Bass.

Lawler III, E. E., \& Worley, C. G. (2006). Built to Change: How to Achieve Sustained Organizational Effectiveness. San Francisco, CA: Jossey-Bass.

Lawrence, P. R., \& Lorsch, J. W. (1967). Differentiation and Integration in Complex Organizations. Administrative Science Quarterly, 12 (1), 1-47.

Levinson, H. (2006). Organizational Assessment: A Stepby-Step Guide to Effective Consulting. Washington, DC: American Psychological Association.

Miller, D. (1988). Relating Porter's Business Strategies to Environment and Structure: Analysis and Performance Implications. Academy of Management Journal, 31 (2), 280-308.
Miller, D., \& Whitney, J. O. (1999). Beyond Strategy: Configuration as a Pillar of Competitive Advantage. Business Horizons, 42 (3), 5-17.

Mintzberg, H. (1979). The Structuring of Organizations: A Synthesis of the Research. Englewood Cliffs, NJ: Prentice Hall.

Mohr, L. B. (1971). Organization Technology and Organization Structure. Administrative Science Quarterly, 16 (4), 444-459.

Morgeson, F. P., \& Humphrey, S. E. (2006). The Work Design Questionnaire (WDQ): Developing and Validating a Comprehensive Measure for Assessing Job Design and the Nature of Work. Journal of Applied Psychology, 91 (6), 1321-1339.

Nadler, D. A., \& Tushman, M. L. (1997). Competing by Design - The Power of Organizational Architecture. New York, NY: Oxford University Press.

Nadler, D. A., Gerstein, M. S., Shaw, R. B. et al. (1992). Organizational Architecture: Designs for Changing Organizations. San Francisco, CA: Jossey-Bass.

Nordsieck, F. (1931). Grundlagen and Grundprinzipien der Organisation des Betriebsaufbaus [Fundamentals and Basic Principles of the Organizational Structure]. Die Betriebswirtschaft [Business Administration Review], 24 (6), 158-162.

Oden, H. W. (1999). Transforming the Organization: A Social-Technical Approach. Westport, CT: Quorum books.

Parker, S. K., \& Wall, T. D. (1998). Job and Work Design: Organizing Work To Promote Well-Being and Effectiveness. Thousand Oaks, CA: Sage Publications.

Pertusa-Ortega, E. M., Zaragoza-Sáez, P., \& Claver-Cortés, E. (2010). Can formalization, complexity, and centralization influence knowledge performance? Journal of Business Research, 63 (3), 310-320.

Porter, L. W., Lawler III, E. E., \& Hackman, J. R. (1975). Behavior in Organizations. New York, NY: McGraw-Hill.

Powell, T. C. (1992). Organizational alignment as competitive advantage. Strategic Management Journal, 13 (2), 119-134.

Pugh, D. S., Hickson, D. J., Hinings, C. R., \& Turner, C. (1968). Dimensions of Organization Structure. Administrative Science Quarterly, 13 (1), 65-105. 
Raisch, B., Birkinshaw, J., Probst, G., \& Tushman, M. L. (2009). Organizational Ambidexterity: Balancing Exploitation and Exploration for Sustained Performance. Organization Science, 20 (4), 685-695.

Reimann, B. C. (1974). Dimensions of Structure in Effective Organizations: Some Empirical Evidence. Academy of Management Journal, 17 (4), 693-708.

Rousseau, D. M. (1978). Characteristics of Departments, Positions, and Individuals: Contexts for Attitudes and Behavior. Administrative Science Quarterly, 23 (4), 521-540.

Rummler, G. A., \& Brache, A. P. (1995). Improving Performance: How to Manage the White Space on the Organization Chart (2 ${ }^{\text {nd }}$ ed.). San Francisco, CA: Jossey-Bass.

Sadler, P. (2001). The Seamless Organization: Building the Company of Tomorrow. London, UK: Kogan Page.

Shani, A. B., \& Docherty, P. (2003) Learning by Design: Building Sustainable Organizations. Malden, MA: Blackwell Publishing.

Spanyi, A. (2003). Business Process Management is a Team Sport. Tampa, FL: Anclote Press.

Spanyi, A. (2006). More for Less: The Power of Process Management. Tampa, FL: Meghan-Kiffer Press.

Sprigg, C. A., Jackson, P. R., \& Parker, S. K. (2000). Production teamworking: The importance of interdependence and autonomy for employee strain and satisfaction. Human Relations, 53 (11), 1519-1543.

Stanford, N. (2005). Organization Design - The Collaborative Approach. Oxford, UK: Elsevier Butterworth-Heinemann.

Steinmetz, J., Bennet, C., \& Hakonsson, D. D. (2012). A Practitioner's View of the Future of Organization Design: Future Trends and Implications for Royal Dutch Shell. Journal of Organization Design, 1 (1), 7-11.

Strikwerda, J., \& Stoelhorst, J. W. (2009). The Emergence and Evolution of the Multidimensional Organization. California Management Review, 51 (4), 11-31.

Skrinjar, R., \& Trkman, P. (2013). Increasing process orientation with business process management: Critical practices. International Journal of Information Management, 33 (1), 48-60.

Telem, M. (1985). The Process Organizational Structure. Journal of Management Studies, 22 (1), 38-52.
Tenner, A. R., \& DeToro, I. J. (1996). Process Redesign: The Implementation Guide for Managers. New Jersey, NJ: Prentice Hall.

Thompson, J. D. (1967). Organizations in Action: Social Science Bases of Administrative Theory. New York, NY: McGraw-Hill.

Turkulainen, V., \& Ketokivi, M. (2013). The Contingent Value of Organizational Integration. Journal of Organization Design, 2 (2), 31-43.

Van de Ven, A. H., \& Ferry, D. L. (1980). Measuring and Assessing Organizations. New York, NY: John Wiley \& Sons.

Van de Ven, A. H. (1976). A Framework for Organization Assessment. Academy of Management Review, 1 (3), 64-77.

Victor, B., \& Blackburn, R. S. (1987). Interdependence: An Alternative Conceptualization. Academy of Management Review, 12 (3), 486-498.

Walton, E., \& Nadler, D. A. (1994). Diagnosis for Organization Design. In A. Howard et al., Diagnosis for Organizational Change: Methods and Models (pp. 85-105). New York, NY: The Guilford Press.

Willem, A. (2006, March). Effects of Organizational Design Dimensions on Inter-unit Knowledge Sharing. Paper presented at OLKC Conference at the University of Warwick, London.

Worren, N. (2012). Organisation design: Re-defining complex systems. Harlow, UK: Pearson.

Zhang, Y., Dolan, S., Lingham, T., \& Altman, Y. (2009). International strategic human resource management: a comparative case analysis of Spanish firms in China. Management and Organization Review, 5 (2), 195-222.

zur Muehlen, M. (2002). Workflow-based Process Controlling. Berlin: Logos Verlag. 